Waldemar Szczerbiński

(Gniezno)

\title{
REKONSTRUKCJONISTYCZNA DESAKRALIZACJA TORY I JEJ WPŁYW NA WSPÓŁCZESNĄ KULTURĘ ŻYDOWSKĄ
}

\begin{abstract}
The text is going to recognize the fact that in the world today it is culture which exerts a tremendous influence on how the Bible is understood by Jews themselves. This approach is exemplified in Jewish reconstructionism, which effected a veritable revolution in that respect. As it appears, the attitude has ultimately led to the desacralization of the Torah.
\end{abstract}

\section{Key words}

Torah, Judaism, desacralization, Jewish reconstructionism 
Biblia była i wciąż pozostaje źródłem inspiracji dla twórców kultury. Widać to zarówno w filozofii, jak i nauce oraz sztuce. Treści biblijne stanowiły dla tych dziedzin kultury albo kontekst odkrycia pewnych idei, albo kontekst ich uzasadnienia. Wpływ Biblii na różne kultury był raczej przypadkowy i wtórny, a zatem niekonieczny. Wpływ tej Świętej Księgi na kulturę Żydów był jednak pierwotny i istotny. W sposób oczywisty zatem wskazuje się na biblijny charakter kultury żydowskiej. Podkreśla się w ten sposób prawdę, że Biblia była elementem konstytutywnym tej kultury. W niniejszych rozważaniach nie chodzi o kolejną analizę wpływu Biblii na kulturę Żydów - to wydaje się oczywiste i powszechnie znane, lecz o dostrzeżenie faktu, że we wspólczesnym świecie to kultura ma ogromny wpływ na rozumienie Biblii przez samych Żydów. Przykładem takiego podejścia jest rekonstrukcjonizm żydowski, który dokonał prawdziwej rewolucji w tej dziedzinie. Jak się wydaje, taka postawa doprowadziła w efekcie do desakralizacji Tory.

Rozważania należy zacząć od refleksji nad żydowskim rozumieniem Biblii i samej kultury. Tradycyjna teologia żydowska przez objawienie rozumie całość Biblii, która została przekazana człowiekowi przez Boga. Jak w judaizmie należy odczytywać owo stwierdzenie? Rabini odróżniają trzy poziomy owego zwracania się Boga do człowieka: poziom Tory, który jest najwyższy i bezpośredni (gdy Bóg przemówił do Mojżesza); poziom prorocki, który jest pośrednim przekazem za pomocą proroctw (nevuah); poziom historyczny, w którym rolę pośrednika spełnia „święty duch” (ruah hakodesh). Z tego powodu zostały ustalone trzy grupy ksiąg biblijnych: Pięcioksiąg, Prorocy i Pisma. Wszystkie zaliczane są do tzw. Tory Spisanej (Torah She-Bi-Ketav). Jest to wąskie rozumienie objawienia w judaizmie. W szerszym znaczeniu obejmuje ono, oprócz Tory Spisanej, także Torę Ustną (Torah She-Be-Al-Peh), która zawiera dodatki i późniejsze adaptacje do nowych warunków. Chodzi tu przede wszystkim o Talmud. Można stwierdzić, że objawienie oznacza w judaizmie albo Pięcioksiąg, albo całość nauczania zawartego w Torze Spisanej i Ustnej, albo całość tradycji ustnej i spisanej wraz ze współczesnymi interpretacjami. Stąd w judaizmie rabinicznym podstawą normatywności i źródłem wiary są zarówno Tora, jak i Talmud. Obie Księgi mają wpływ na kształt kultury żydowskiej.

Czym jest kultura żydowska? ${ }^{1}$ Istotne jest, czy będziemy posługiwać się terminem „kultura żydowska”, czy „kultura judaizmu”, czy też „kultura izraelska”. Zbyt często spotykamy się bowiem z utożsamieniem określeń: „żydow-

\footnotetext{
${ }^{1}$ Na temat kultury żydowskiej zob. Szczerbiński 2014, s. 79-107.
} 
ski”, „judaistyczny”, „izraelski”. Wydawać by się mogło, że w odniesieniu do rozumienia kultury jako humanizacja natury ${ }^{2}$ sprawa nie nastręcza większych trudności. Okazuje się jednak, że słowo „kultura” jest nieostre. John Storey za Raymondem Williamsem podkreśla, że kultura jest jednym z najbardziej wieloznacznych terminów $\mathrm{w}$ języku angielskim ${ }^{3}$. Nie inaczej jest $w$ innych językach, w tym w języku polskim. Najczęściej terminu „kultura” używamy $\mathrm{w}$ jednym $\mathrm{z}$ trzech znaczeń. Po pierwsze, kultura może oznaczać określone procesy, zjawiska, nurty intelektualne, estetyczne czy duchowe. W tym sensie, mówiąc lub pisząc o kulturze w Izraelu, przywołujemy wybitne dzieła filozofów, malarzy, poetów, stanowiące kanon żydowskiej sztuki, filozofii, literatury. Po drugie, słowo kultura odnosi się do stylów życia, wyznawanych systemów wartości jakichś grup ludzi w określonym czasie i przestrzeni. Opisując kulturę żydowską $\mathrm{z}$ tej perspektywy, uwaga zostaje skierowana nie tylko (czy niekoniecznie) na prądy intelektualne i estetyczne oraz ich głównych przedstawicieli, ale także na festiwale, imprezy sportowe, obchody świąt państwowych czy religijnych. Po trzecie, pojęcie kultury może być używane w do pracy i praktyk intelektualnych oraz specyficznej artystycznej, czy szerzej - performatywnej aktywności. Innymi słowy, kulturę traktuje się wówczas jako teksty i praktyki pełniące funkcję znaków (kodów) produkujących lub stwarzających okazję do tworzenia znaczeń. W tym ujęciu termin „kultura” jest bliski strukturalistycznemu i poststrukturalistycznemu konceptowi „znaczących praktyk” (signifying practices). Owe „znaczące praktyki” to np.: opera, balet, powieści. Pisząc o kulturze popularnej, odwołujemy się przede wszystkim do drugiego i trzeciego znaczenia terminu „kultura”. Tak rozumiana, jako określone style życia i systemy wartości, pozwala przyjrzeć się rozmaitym formom społecznej aktywności, takim jak: spędzanie wolnego czasu, robienie zakupów czy celebrowanie świąt. $\mathrm{Z}$ kolei trzecie ujęcie - kultura jako signifying practices umożliwia analizę scenariuszy, tzw. oper mydlanych, pop muzyki, komiksów jako przykładów kultury (popularnej).

Trudności jednak pojawiają się $\mathrm{w}$ zestawieniu kultury $\mathrm{z}$ „tym, co jest żydowskie". Kultura żydowska może być rozpatrywana podmiotowo lub przedmiotowo. Od strony podmiotowej kultura żydowska oznacza kulturę, którą tworzą Żydzi. Od strony przedmiotowej charakteryzuje ją to, że treściowo jest właśnie żydowska. Wyłaniają się jednak kolejne problemy. Nie jest łatwo określić, kogo uznać za Żyda, i co stanowi o tym, że coś jest żydowskie.

\footnotetext{
${ }^{2}$ Zob. Chat 2009, s. 44.

${ }^{3}$ Storey 2009, s. 1-2.
} 
Odpowiedź zależy od tego, jakie zastosujemy kryterium. Na pojęcie „bycia Żydem” składają się różne kategorie, które są niezależne od siebie. Unterman wskazuje na cztery: „pochodzenie biologiczne, wyznanie, przynależność do wspólnoty kulturowej oraz przynależność etniczna lub państwowa i język, jakiego się używa"4. Niezależność tych kategorii powoduje, że o „żydowskości” mogą decydować wszystkie naraz kategorie, niektóre $\mathrm{z}$ nich lub tylko jedna z nich. Warto zwrócić uwagę, że w Izraelu poszczególne środowiska traktują te wyznaczniki w różny sposób. Motywy wyboru kryterium bywają różne. Pojęcie rasy można porzucić jako kryterium przyrodnicze. Posługiwanie się tym kryterium jest uprawnione $\mathrm{w}$ obrębie biologii pod warunkiem, że nie wyciąga się z ustalonych wniosków sądów wartościujących. Ponadto faktem bezspornym jest wielorasowość Żydów, a treści myślenia nie są uwarunkowane biologicznymi odmianami występującymi wśród ludzi.

Kulturę, jako fenomen duchowy, trzeba pojmować w aspektach historycznych i wyjaśniać ją na podstawie warunków społecznych. Żydowskie środowisko i przyswojona tradycja, a nie rasowe pochodzenie, kształtują świadomość i mogą znaleźć wyraz także w kulturze. W czasach nowożytnych zaistniał problem dotyczący dwóch pozostałych kryteriów: czy Żydzi są wspólnotą narodową, czy religijną, czy też jednym i drugim? Na to pytanie sami Żydzi udzielają różnych odpowiedzi, w zależności od stopnia asymilacji w społeczeństwie, w którym żyją. Żydzi w starożytności i w średniowieczu stanowili grupę narodową i religijną zarazem i był to związek nierozerwalny także po ustaniu odrębnej państwowości żydowskiej. Nazwa „Żydzi” egzystowała równolegle do nazw innych narodów, jak Grecy czy Egipcjanie. Mimo że żyli w rozproszeniu, utrzymywali swoją narodowość dzięki religii. Dopuszczali asymilację w stopniu nieszkodzącym integralności wspólnoty. Nigdy też nie porzucono nadziei na odzyskanie narodowej samodzielności, co stało się faktem po II wojnie światowej. W średniowiecznej chrześcijańskiej Europie słowo „Żyd” stało się równoległe wobec słów „chrześcijanin” czy „muzułmanin”. Przynależność religijną uznano za kryterium określające Żyda. Jak cechą charakterystyczną w starożytności była przynależność narodowa, tak w średniowieczu cechą tą była wyznawana religia. W późniejszym okresie, gdy Żydzi stawali się obywatelami poszczególnych państw, czynnikiem wyróżniającym pozostało wyznawanie własnej religii. Pewnym wyjątkiem są wschodnioeuropejscy Żydzi, którzy stanowili odrębną wspólnotę kulturową, posługiwali się własnym językiem zwanym jidisz, a tożsamość wiązali

${ }^{4}$ Unterman 2002, s. 19. 
w znacznym stopniu z aspektem narodowej niezależności. Obecnie przyznawanie się do religii żydowskiej (judaizm) i do narodu żydowskiego (syjonizm) jest wystarczającym kryterium klasyfikacji lub samookreślenia się Żyda. Jedność obu komponentów nie jest już rzeczą konieczną. Tak też jest w Izraelu. Język jako dodatkowy wyróżnik często nie był i nie jest związany z tym, co żydowskie. Kultura żydowska pozostawała oddzielona od arabskiej, pomimo posługiwania się przez sefardyjskich Żydów w starożytności językiem arabskim. W czasach nowożytnych Żydzi posługują się zazwyczaj językiem środowisk, w których zamieszkują. Kulturze żydowskiej brakuje więc językowej jednolitości, a jej dzieła spisane są w języku hebrajskim, jidisz, ladino oraz w języku kraju przebywania. Także w Izraelu nośnikiem kultury nie jest jedynie hebrajski, mimo że jest on oficjalny, preferowany i nauczany.

Kultury żydowskiej nie należy przeciwstawiać kulturze jako takiej. Dookreślenie „żydowska” funkcjonowało w przeszłości w kontraście do filozofii chrześcijańskiej oraz muzułmańskiej, i opierało się na kryterium religijnym. Średniowieczną kulturę żydowską cechowało bycie abstrakcyjnym przeciwieństwem w stosunku do kultury islamskiej i chrześcijańskiej. Nowożytna kultura żydowska nie zacieśnia się do religii, a judaizm pojmuje się często tylko jako przeszłe dziedzictwo, bez konotacji sakralnej. Stąd współcześnie tworzący Żyd nie jest już tożsamy z twórcą religijnym. Sprawę komplikuje dodatkowo fakt, że wielu żydowskich twórców identyfikuje się i utożsamia z kulturą krajów przebywania lub kulturą narodów, wśród których mieszkają. Powyższe rozważania prowadzą nas do postawienia kluczowego pytania: czy o żydowskości kultury decyduje jej podmiotowość czy przedmiotowość? Czy kultura dlatego jest żydowska, że jej twórcą jest Żyd? (podmiotowe podejście), czy też dlatego, że jej treść ma charakter żydowski, nawet jeśli autor nie jest Żydem (podejście przedmiotowe)? A może podmiot i przedmiot zarazem muszą być żydowskie? Jeśli jednak kryterium tego, co żydowskie, nie jest związane z judaizmem lub judaizm traktuje się jako kulturę, a nie religię, to co decyduje o żydowskości? Może ma rację Heschel, twierdząc, że separacja wiary i wszelkiego działania, jak gdyby były one dwoma oddzielnymi
przedziałami, może jedynie doprowadzić do schizofrenii judaizmu. Ponadto,
mówienie o judaizmie jako o sposobie życia, gdzie wiara zajmuje drugie miejsce,
jest uczynieniem niesprawiedliwości w stosunku do judaizmu

Reasumując, przez całe tysiąclecia kultura żydowska miała charakter wybitnie religijny, co decydowało o jej wyjątkowości i specyfice. Można ją

\footnotetext{
${ }^{5}$ Kaufman 1976, s. 6.
} 
nazwać kulturą judaistyczną i biblijną jednocześnie. Jednak od czasów oświecenia żydowskiego, w wyniku procesów asymilacyjnych, pojawiły się w niej elementy, które zrywały z ciągłością historyczną, wyznaczając nowe kryteria tożsamości żydowskiej. Judaizm rozumiany jako religia przestał być koniecznym wyznacznikiem żydowskości. Tym samym kultura żydowska jako kultura religijna bądź też kultura związana $\mathrm{z}$ religią, a tym samym z Biblią, przestała być jedyną i dominującą formą żydowskości. Od czasów Haskali żydowska specyfika w sferze kultury możliwa jest nie tylko w granicach religijnych. Tożsamość żydowska oparta o kryterium narodu znajduje ideologiczny wyraz $\mathrm{w}$ teorii politycznej, $\mathrm{w}$ ramach której znajduje się syjonizm. Ponieważ termin „kultura żydowska” nie implikuje już w sposób konieczny związku kultury z religią żydowską, uzasadnione jest mówienie o niej także w sytuacji, gdy takiego związku nie ma lub gdy przejawy kultury żydowskiej stoją nawet w wyraźnej sprzeczności z judaizmem i przesłaniem biblijnym. W dobie rugowania religii z szeroko rozumianej kultury religijna koncepcja kultury żydowskiej niejednokrotnie budzi sprzeciw. Próby dyskredytacji kultury związanej z religią płyną nie tylko z zewnątrz, ale i z wewnątrz danej grupy religijnej. Najczęściej powodem tego jest dostosowywanie się kultury czy samych twórców do przyjętych w danym czasie paradygmatów, rozumienia kultury oraz jej roli w społeczeństwie. Taka presja doprowadza coraz częściej do porzucenia jej istotnych wymiarów.

Problem kultury żydowskiej zaczyna się już od rozumienia terminu „kultura”. Mówienie o totalnej separacji i neutralności światopoglądowej na terenie kultury wydaje się czystym anachronizmem i nie rozwiązuje problemu. Gdyby tak było, niepotrzebne by były praktyki jej dookreślania. Nie było by wówczas kultury arabskiej, żydowskiej, chrześcijańskiej ani nawet laickiej. Od czasu powstania państwa żydowskiego możemy mówić o kulturze izraelskiej, która jest przedmiotem rozważań. W Izraelu przynależność do wspólnoty kulturowej nie jest też sprawą oczywistą. Życie każdej wspólnoty, także żydowskiej, zawiera elementy społeczne i kulturowe na równi z religijnymi. Powstaje pytanie, czy w przypadku Żydów możemy mówić o wspólnocie kulturowej. Wydaje się, że uznając nawet jej istnienie, trzeba jasno stwierdzić, że jest ona niejednorodna, wręcz ogromnie zróżnicowana, i stanowi wypadkową wielu kultur.

Erich Fromm dostrzegł, że „nie było takiej kultury w przeszłości - i jak się zdaje - nie może być takiej kultury w przyszłości, która by nie miała religii”.

${ }^{6}$ Fromm 1968, s. 124. 
Fenomen religijny stanowi zatem jeden z najbardziej powszechnych wyrazów ducha ludzkiego zarówno w sensie jednostkowym, jak i społecznym. Kultura jest przetwarzaniem natury, które pozostawia na niej ślad swoiście ludzki. W tym kontekście można powiedzieć, że religia dąży do czegoś więcej, do sakralizacji natury.

Religia jest dziedziną kultury, ale ją zarazem w swych tendencjach transcenduje. Zachodzi pewna odrębność porządku kultury jako porządku naturalnego (sfera aktywności człowieka) i porządku religii, który jest porządkiem wiary, przekraczającym porządek natury i znajdującym swe uzasadnienie nadprzyrodzone ${ }^{7}$.

Między postawą religijną człowieka, która dąży do sakralizacji, do uświęcenia świata a sekularyzacją i desakralizacją staje rzeczywistość ziemska, życie doczesne z techniką, nauką i kulturą. Wartością dla religii jest świętość, która w żaden sposób nie pokrywa się z żadną inną wartością kultury (prawdą w nauce, dobrem - w etyce, pięknem - w sztuce). Świętość jest wartością, która przenika inne wartości ludzkie ${ }^{8}$. W pierwotnym zamyśle Żydzi mieli być ludem świętym, a Tora, która traktowana była jako święta, wyznaczała drogę osiągnięcia świętości. Wydaje się zatem, że rozwój żydowskiej kultury pozbawionej wymiaru religijnego traci swój historyczny sens.

\begin{abstract}
Sekularyzacja (zeświecczenie) oznacza proces społeczno-kulturowy, w wyniku którego różne dziedziny życia społecznego, jak: polityka, życie gospodarcze, nauka, filozofia, kultura, oświata, szkolnictwo, wychowanie wyzwalają się stopniowo spod kontroli organizacji wyznaniowych, stają się niezależne od instytucji religijnych i kościelnych? .
\end{abstract}

Współcześnie sekularyzm wiąże się raczej z pewnym typem mentalności naukowo-technicznej i racjonalistycznym sposobem myślenia, przedstawiającym obraz świata bez Boga, kwestionującym transcendentną wartość samego człowieczeństwa. W naukach społecznych "sekularyzacja” występuje w różnych znaczeniach: jako upadek lub zanik religii (instytucje religijne, dogmaty wiary i wartości religijne tracą swój dawny wpływ na społeczeństwo), jako przystosowanie się do świata (dotyczy grupy religijnej, która utworzyła się na religijnych podstawach, lecz w miarę upływu czasu zatraca swoją religijną odrębność), jako desakralizacja (odejście od religijnego rozumienia świata na rzecz logiczno-przyczynowego wyjaśniania zachodzących zjawisk), jako odłączenie społeczeństwa od religii (religia ogranicza się wówczas do życia prywatnego $)^{10}$. W odniesieniu do Biblii desakralizacja jest

\footnotetext{
${ }^{7}$ Chat 2009, s. 46.

${ }^{8}$ Zob. Zdybicka 1977, s. 317.

${ }^{9}$ Chat 2009, s. 114-115.

${ }^{10}$ Więcej na temat sekularyzacji zob. Radwan 1967; Piwowarski 1998; Baniak 2006, s. 272-289.
} 
niczym innym jak odejściem od tradycyjnej interpretacji na rzecz naukowego wyjaśniania jej autorstwa, treści i znaczenia.

Od problemu desakralizacji nie jest wolny i judaizm.

Faktem jest, że od dwustu lat Żydzi przeżywają prawdziwy kryzys tożsamości (...). Czy judaizm jest religią, cywilizacją czy kulturą? (...) Ten kryzys wiary stanowiący najważniejszy problem, jakiemu musi stawić czoło judaizm, pogłębił się w drugiej połowie XX wieku, a w obliczu Holokaustu przybrał dramatyczne wprost rozmiary ${ }^{11}$.

Powodem tego dramatu ludzkiego $\mathrm{w}$ judaizmie jest zwątpienie albo w istnienie Boga albo w Jego istotę. Wielu młodych Żydów utrzymuje,

\begin{abstract}
że odziedziczony po przodkach Bóg Żydów stoi na przeszkodzie ich dzisiejszemu normalnemu życiu. Przyszłość należy do wskrzeszonego narodu żydowskiego, który może kształtować swoje życie według własnej woli ${ }^{12}$.
\end{abstract}

Wielu współczesnych myślicieli żydowskich podejmowało próbę przezwyciężenia tego impasu poprzez wypracowanie takiej koncepcji judaizmu, która - ich zdaniem - byłaby najbardziej adekwatna i pomocna w odrodzeniu prawdziwej wiary w Boga. Z pewnością wynikało to $\mathrm{z}$ ich troski oraz świadomości odpowiedzialności za przyszłość judaizmu. Wśród tych propozycji odnajdujemy koncepcję Kaplana, który jest twórcą rekonstrukcjonizmu żydowskiego. Stanowisko Kaplana wiąże się tym samym z negacją tradycyjnej wiary w Boga, która ma swoją przyczynę egzystencjalną (Bóg nie wpływa na losy Żydów, czego dowodem są wydarzenia II wojny światowej) i scjentystyczną (odrzucenie teorii kreacji jako niezgodnej z nauką).

Idea,

w myśl której historia i kultura, a nie teologia, definiują zbiorową tożsamość, pociągała niektórych współczesnych Żydów, chcących zachować swoją żydowskość. Pozwalała im pozostać tą częścią przeszłości, którą chcieli zachować, dodając do niej nowe elementy i odrzucając całą resztę ${ }^{13}$.

Ta idea towarzyszyła Kaplanowi i jego zwolennikom, którzy zaczęli patrzeć na Torę przez pryzmat kultury (nauki, filozofii i sztuki), odchodząc tym samym od patrzenia na kulturę przez pryzmat Tory. Jest to rezultat pluralizmu, który ogarnia coraz częściej dziedzinę religijną.

Tak zwana teologia pluralizmu religijnego, z tego punktu widzenia może być interpretowana jako symptom zagubienia, któremu towarzyszy zaciemnienie, otwierające drogę nowym formom barbarzyństwa. Można w niej rozeznać znaki unoszenia przez każdą falę i chwiania się na każdym wietrze (...). Wszystkie te teorie domniemanego pluralizmu wychodzą od odrzucenia prawdy Objawienia judeo-

\footnotetext{
${ }^{11}$ Eisenberg 1999, s. 129-130.

${ }^{12}$ Ibidem, s. 216

${ }^{13}$ Ibidem.
} 
chrześcijańskiego lub od wpędzenia człowieka na powrót w kondycję przedmojżeszową i przedchrześcijańską. Nie ma już więcej możliwości, aby zastosować rozróżnienie pomiędzy religią naturalną i objawioną, i nawet jeśli zaistniało jakieś objawienie, posiada ono według obowiązującej logiki, charakter prowizoryczny, nie definitywny, cząstkowy, a zatem także nie jest ostatecznie wiążące ${ }^{14}$.

Należało by stwierdzić dzisiaj, że wszyscy wyznawcy judaizmu odwołują się do Biblii, ale poszczególne grupy w judaizmie różnią się, i to w sposób istotny, interpretacją Tory i Talmudu.

Talmud to nie interpretacja Biblii, lecz miejsce jej interpretacji przez żydów. Kiedy mistrz Talmudu zaproponuje takie czy inne znaczenie któregoś wersetu lub słowa z Biblii, natychmiast znajdzie się drugi, który powie coś wręcz przeciwnego, a po nim trzeci coś jeszcze innego. Nie ma tu prawdy ostatecznej, a jedynie określone znaczenie lub znaczenia, które są sobie przeciwstawne, korygują się wzajemnie i uzupełniają. Prawdziwy sens polega właśnie na tym zderzeniu różnych znaczeń, na przekonaniu, że żadne sformułowanie nie będzie nigdy ostateczne $e^{15}$.

Współczesny judaizm nie jest monolitem. Wśród wszystkich dzisiejszych nurtów najnowszym i najbardziej kontrowersyjnym okazuje się rekonstrukcjonizm żydowski. Wszystkie inne (ortodoksyjne, reformowane, konserwatywne) reprezentują teizm żydowski, który $\mathrm{w}$ najistotniejszych sprawach zachowuje wierność tradycji. Dlatego w judaizmie można mówić o teistycznej koncepcji Boga, która w różnych postaciach odzwierciedla dziedzictwo przeszłości. Tymczasem punktem wyjścia rekonstrukcjonizmu jest właśnie rekonstrukcja judaizmu tradycyjnego, która dokonuje się w oparciu o idee zaczerpnięte $\mathrm{z}$ nauk przyrodniczych i społecznych. Przy takim podejściu nie wiara, lecz wiedza stanowi kryterium właściwej interpretacji Biblii. Bez wątpienia rekonstrukcjonizm przekroczył granice teizmu żydowskiego i postawił się w opozycji do niego. Judaizm w rozumieniu Kaplana jest cywilizacją, a nie jak dotychczas, religią. Religia jest tylko jednym $\mathrm{z}$ wielu elementów cywilizacji, która wcale nie jest najważniejsza, najistotniejsza i bezwarunkowa. Podejście do Biblii w rekonstrukcjonizmie nie tylko może, lecz wręcz musi, zmieniać się tak, jak inne składniki cywilizacji żydowskiej. Od tej pory nie trzeba być teistą, aby pozostać wyznawcą judaizmu. To jest całkowita nowość w świecie żydowskim. Rekonstrukcjonista nie akceptuje supernaturalizmu (nadprzyrodzoności), a co za tym idzie, nie uznaje boskiego pochodzenia Tory, teorii kreacji, cudów, życia wiecznego w innym świecie. Postulat nie-osobowego Boga jest wynikiem zanegowania supernaturalizmu i tradycyjnej soteriologii żydowskiej.

\footnotetext{
${ }^{14}$ Serretti 2006, s. 10-11.

${ }^{15}$ Ouaknin 1998, s. 54-55.
} 
Wyłania się pytanie, w jaki sposób współczesna kultura wpłynęła na interpretację Biblii w rekonstrukcjonizmie żydowskim. Tradycyjny judaizm, zwany obecnie teizmem żydowskim, reprezentowany jest w większym lub mniejszym stopniu przez ortodoksów, reformatorów i konserwatystów ${ }^{16}$. Wymienione denominacje, pomimo różnic, utrzymują wciąż tradycyjne rozumienie judaizmu i żydowskich prawd wiary. Budowanie przez Kaplana nowej wizji judaizmu poprzedzone jest krytyką wspomnianych wyżej grup ${ }^{17}$. Według Kaplana teistyczny judaizm, który był charakterystyczny dla przeszłości i wciąż jest bezzasadnie podtrzymywany, jest nie do przyjęcia dla współczesnego Żyda. Dlatego wyłoniła się potrzeba chwili, aby głoszone od wieków zasady zrekonstruować, $\mathrm{i}$ to $\mathrm{w}$ taki sposób, który uwzględniałby zarówno tradycję, jak i osiągnięcia nowożytnej nauki. Aby osiągnąć ów cel, należy, jak postulował ${ }^{18}$, wniknąć w inspiracje tradycji żydowskiej i podtrzymać jej siłę; zreinterpretować tkwiące $\mathrm{w}$ tradycji fakty, wartości, historię, literaturę za pomocą pojęć współczesnej nauki; postrzegać judaizm jako ustawicznie rozwijającą się religijną cywilizację, unikając jednocześnie błędu dychotomii między tym, co świeckie, a tym, co religijne; położyć społeczne i duchowe fundamenty pod organicznie demokratyczne funkcjonowanie wspólnoty żydowskiej i jej różnych instytucji; zaszczepić w grupach żydowskich nową moc twórczą, która pozwoli im odkryć w judaizmie standardy nauki, moralności i wszelkich wartości; dodać duchowego znaczenia i motywacji życiu jednostki i grupy; odnieść życie wspólnoty żydowskiej do społeczeństwa amerykańskiego i spraw światowych.

Istotą judaizmu tradycyjnego było przeniknięcie wszystkiego religią, uczynienie sacrum z profanum. Haskala dążyła do ograniczenia tej dominacji poprzez wyznaczenie religii jej miejsca i wyodrębnienie świeckiej - humanistycznej rzeczywistości żydowskiej. Kaplan nie odrzucał tradycji. Kierując się zasadami haskali, krytykował wszelki dogmatyzm i nietolerancję, dążył do reinterpretacji teizmu żydowskiego. W przeszłości zmiany, które dokonywały się $\mathrm{w}$ judaizmie, były nieznaczne $\mathrm{i}$ nieistotne $\mathrm{w}$ porównaniu $\mathrm{z}$ radykalną modyfikacją, której dokonał Kaplan. Dla religijnych Żydów jakiejkolwiek przynależności z pewnością najbardziej kontrowersyjnym aspektem myśli

\footnotetext{
${ }^{16}$ Ortodoksja stoi na stanowisku, że niczego nie można zmienić. Reforma pragnie zmienić wszystko w oparciu jedynie o sumienie jednostki. Ruch konserwatywny opowiada się za częściowymi zmianami, o których może decydować tylko wspólnota, a nie poszczególny człowiek. Sami Żydzi opisują te grupy jako: crazy (szaleni) - judaizm ortodoksyjny; lazy (leniwi) - judaizm reformowany; hazy (zamglony) - judaizm konserwatywny.

${ }^{17}$ Zob. Kaplan 1981, s. 91-169.

${ }^{18}$ Zob. Chipkin 1952, s. 85-118.
} 
Kaplana była jego antyantropomorficzna, antypersonalistyczna i antysupernaturalistyczna koncepcja Boga, z której wynikały wszelkie inne przekonania ${ }^{19}$.

„Metoda, którą posługiwali się starożytni, może być nazwana transwalua$c_{j} a^{20}$; metodę, która musimy się posługiwać możemy nazwać rewaluacją ${ }^{21 " 22}$. W opinii Kaplana transwaluacja jest charakterystyczna dla tradycyjnego judaizmu, który stosował ją jako narzędzie umożliwiające religii żydowskiej zachowanie ciągłości ${ }^{23}$. Jego zdaniem zarówno tradycja wyartykułowana w okresie rabinicznym, jak i przez późniejszych alegorystów żydowskich nadawała nowe znaczenia i wartości pierwotnym tekstom judaizmu. Według Kaplana dokonująca się przez wieki transwaluacja nie jest możliwa dzisiaj. Wprost stwierdza: „Metoda transwaluacji nie może odgrywać takiej samej roli dla współczesnego Żyda"24. Troska o zachowanie ciągłości judaizmu współczesnego z judaizmem czasów przeszłych lub też przejście od judaizmu tradycyjnego do judaizmu przyszłości „może być osiągnięte jedynie w pełnym świetle całkowitej świadomości zmiany, w którą uwikłany jest judaizm”25. Rozwój nauki zmienił naszą świadomość i poszerzył nasze możliwości poznawcze. Dotyczy to również dziedziny religii. Jak sugeruje Kaplan, dziś wiemy, że właściwych znaczeń, sensów i wartości nie można szukać w narosłej tradycji, lecz w pierwotnych źródłach judaizmu. „Z tego powodu musimy odrzucić transwaluację i uciec się do rewaluacji" ${ }^{26}$. Transwaluacja jest powielaniem tego, co już było w nowej oprawie, a co nie jest możliwe do realizacji obecnie. „Rewaluacja polega na wyodrębnieniu z tradycyjnej treści tych elementów, które odpowiadają permanentnym postulatom natury ludzkiej oraz na integrowaniu ich z naszą własną ideologią" ${ }^{27}$. Jak wyjaśnia Kaplan dalej:

Kiedy dokonujemy rewaluacji, analizujemy lub rozkładamy na czynniki pierwsze wartości tradycyjne w ich całościowej zawartości, które mogą pomóc nam dostrzec nasze własne potrzeby moralne i duchowe; reszta może zostać oddana z powrotem archeologii ${ }^{28}$.

\footnotetext{
${ }^{19}$ Por. Seltzer 1990, s. 10.

${ }^{20}$ Transvaluation - transwaluacja lub transwaloryzacja. Chodzi o przewartościowanie lub nadanie nowej wartości (przekształcenie wartości).

${ }^{21}$ Revaluation - rewaluacja lub rewaloryzacja. Należy to rozumieć jako powrót do pierwotnej wartości lub przywrócenie wartości.

${ }^{22}$ Kaplan 1962, s. 3.

${ }^{23}$ Kaplan utrzymywał, że odniesienia rabiniczne do tekstu pisanego (Tory) ujawniają dość dużą niezgodność z literalnym znaczeniem tekstu. Aby temu zapobiec, należy poddać badaniom oryginalne źródła tradycji żydowskiej. Zob. ibidem, s. 3-4.

${ }^{24}$ Ibidem, s. 6.

${ }^{25}$ Ibidem.

${ }^{26}$ Ibidem.

${ }^{27}$ Ibidem.

${ }^{28}$ Ibidem.
} 
Dodatkowo, rewaluacja idei religijnej lub instytucji religijnej może dokonać się tylko poprzez zrozumienie tychże fenomenów w świetle całościowej sytuacji, której były częścią ${ }^{29}$.

Kaplan miał własne rozumienie „najwyższego pojmowalnego celu” ludzkiej egzystencji. Tym celem jest pomoc w stworzeniu społeczności, które wychowa osoby zmotywowane przez to, co nazwał sensem aktywnej odpowiedzialności moralnej.

Dla nas Żydów nie może istnieć żaden wyższy cel niż odzwierciedlanie sztuki życia, indywidualnie i zbiorowo, tak, aby wnieść swój udział w intelektualny, moralny i duchowy postęp ludzkości (...). Typ religii, którego my Żydzi jako lud i ludzkość, jako całość niezmiernie potrzebujemy jako środka do przetrwania, musi przybrać taką formę, która umożliwi moralną odpowiedzialność w działaniu ${ }^{30}$.

W przekonaniu Kaplana taki rodzaj religii pomógłby ludzkości uwolnić się od trzech iluzji, które jej zagrażają w czasach współczesnych: 1) iluzji kolektywizmu, 2) iluzji nieugiętego indywidualizmu, 3) iluzji niezmienności natury ludzkiej ${ }^{31}$. W terminach filozofii współczesnej judaizm w rozumieniu rekonstrukcjonistów jest egzystencjalnie ludem żydowskim, esencjalnie religią żydowską, funkcjonalnie żydowskim sposobem życia ${ }^{32}$.

Całkowicie nowym fenomenem w myśli żydowskiej jest rekonstrukcjonistyczna „teologia transnaturalna”, której zamiarem jest „zbudowanie teologii filozoficznej, która unika zarówno supernaturalizmu jak i naturalizmu redukcyjnego" ${ }^{33}$. Można śmiało stwierdzić, że to stanowi dla Kaplana punkt wyjścia dla całego systemu myśli. Punkt wyjścia rozumiany jest zazwyczaj albo jako pierwsza czynność, albo jako pierwsza teza ${ }^{34}$. Pierwszą czynnością jest u Kaplana właśnie odrzucenie supernaturalizmu (nadnaturalności, nadprzyrodzoności). Pierwszą tezą jest natomiast: cogito ergo vivo ${ }^{35}$. Taki punkt wyjścia burzy fundament judaizmu tradycyjnego, którego podstawą w sensie czynności jest całkowita akceptacja objawienia, a w sensie pierwszej tezy jest: credo ergo vivo. Kaplan przedstawia swoje rozumienie transnaturalizmu w następujących słowach:

\footnotetext{
${ }^{29}$ Zob. ibidem, s. 7.

${ }^{30}$ Kaplan 1964, s. 294.

${ }^{31}$ Por. Goldsmith 1990, s. 22.

${ }^{32}$ Por. ibidem, s. 24.

${ }^{33}$ Kaufman 1981, s. 45-52.

${ }^{34} \mathrm{U}$ Kartezjusza pierwszą czynnością było wątpienie, a pierwsza tezą: cogito ergo sum.

${ }^{35}$ Vivo (łac.) - w znaczeniu zostawać przy życiu, trwać, utrzymywać się, spędzać życie, żyć z kimś w zażyłości, być szczęśliwym.
} 
Transnaturalizm jest takim rozwinięciem naturalizmu, który bierze pod uwagę sporo z tego, czym są w stanie zajmować się nauki mechanistyczne, materialistyczne lub pozytywistyczne. Transnaturalizm sięga $\mathrm{w}$ dziedzinę, gdzie rozum, osobowość, cel, ideały, wartości i znaczenia występują. Uwzględnia to, co dobre i to, co prawdziwe. Czy ma to swoją własną logikę, jest problematyczne. Z pewnością jednak ma swój język, język porównania, metafory i poezji. Jest to język symbolu, mitu i dramatu. W świecie dyskursu wiara w Boga oznacza wiarę w życie i w człowieka, która jest w stanie transcendować potencjalności zła tkwiące w zwierzęcej dziedziczności, w społecznym dziedzictwie, w uwarunkowaniach środowiska. Transnaturalistyczna religia dostrzega Boga w dopełnieniu ludzkiej natury, a nie w zawieszeniu porządku natury. Jego zadaniem nie jest wspomaganie człowieka $\mathrm{w}$ pokonaniu niebezpieczeństw natury, lecz uzdolnienie go do tego, aby poddał kontroli to, co nieludzkie w stosunku do innych istot ludzkich ${ }^{36}$.

Rekonstrukcjonistyczna negacja supernaturalizmu jest rezultatem dążenia, aby wypracować taką teorię judaizmu, która nie zakłada zawieszenia porządku natury. Pod tym względem jest zgodna $z$ typowym naturalizmem ${ }^{37}$. Supernaturalizm, jak go rozumiał Kaplan, jest poglądem, w którym Bóg nie podlega empirycznemu prawu natury i z tego powodu może zawieszać naturalny porządek w każdym miejscu i w każdym czasie. Biblijne cuda, interpretowane w tradycyjny sposób zawierają tego rodzaju zawieszenie. Kaplan odrzuca historyczność wszelkich cudów i logikę supernaturalizmu, które są widoczne $\mathrm{w}$ tradycji żydowskiej. Uważa, że paradygmat nadprzyrodzoności $\mathrm{w}$ teologii jest jedynie założeniem, i to niefilozoficznego umysłu. Kaplan wyjaśnia:

Naturalność ma specyficzne znaczenie, które należy skorygować jako jedno z głównych założeń niefilozoficznego umysłu. Oznacza fakt, że działanie każdej rzeczy jest uwarunkowane przez prawo jej własnego bytu. To prawo nie może być zmienione przez jakąkolwiek wolę działającą wewnątrz i na zewnątrz. Dla niefilozoficznego lub nienaukowego umysłu wszystkie rzeczy jawią się jako byty działające w oparciu o coś zewnętrznego przez quasi-ludzkie wole lub pojedynczą quasi-ludzką wolę. Pomijając twierdzenia apologetów filozoficznych Bóg jest pojmowany w Biblii i w literaturze rabinicznej bardziej lub mniej antropomorficznie. Jego wola, aczkolwiek nieskończenie nieograniczona w mocy, sprawiedliwość i dobroć w stosunku do człowieka, odpowiada w świadomości człowieka specyficznym celom, które stara się osiągnąć. Z tego punktu widzenia nic nie posiada prawa swojego własnego bytu ${ }^{38}$.

\footnotetext{
${ }^{36}$ Kaplan 1958, s. 10.

${ }^{37}$ Naturalizm (łac. naturalis) - w sensie najbardziej ogólnym to opowiedzenie się za tym, że w ostatecznym rachunku nic nie jest w stanie oprzeć się wyjaśnieniu za pomocą metod charakterystycznych dla nauk szczegółowych. W sensie metafizycznym stanowisko uznające naturę w znaczeniu kosmologicznym za ostateczną rację jej własnego istnienia i działania oraz odrzucające istnienie wszelkiego bytu transcendentnego. Naturalizm znajduje najczęściej wyraz w materializmie i panteizmie. Naturalizmem nazywa się w szczególności popularną w Stanach Zjednoczonych odmianę materializmu E. Nagla.

${ }^{38}$ Kaplan 1958, s. 314-315.
} 
Zakwestionowanie przez rekonstrukcjonistów porządku nadprzyrodzonego bazuje na przekonaniu, że współczesna nauka i filozofia wypracowały wspólnie autonomię porządku naturalnego, co nie pozwala na dalsze tolerowanie jakichkolwiek form supernaturalizmu ${ }^{39}$. Takie stanowisko miało ogromny wpływ na interpretację Biblii.

Zazwyczaj Kaplan jest znany jako twórca własnych koncepcji: żydowskiego ludu, judaizmu rozumianego jako cywilizacja i poszukiwania znaczenia Boga w ludzkim doświadczeniu. Niewielu postrzega twórcę rekonstrukcjonizmu jako interpretatora Biblii ${ }^{40}$. Tymczasem jego argumenty nie tylko bazują na tekstach biblijnych, lecz także odnajdujemy wypowiedzi, które wprost omawiają jego koncepcję Tory. Trzeba jednak podkreślić, że w jego dziełach nie znajdziemy systematycznej prezentacji jego teologii biblijnej czy też powszechnie znanej biblijnej narracji.

Kaplan Biblię znał bardzo dokładnie. Poznawał jej tajniki jako student, a następnie sam prowadził wykłady związane $\mathrm{z}$ Biblią $\mathrm{w}$ Jewish Theological Seminary. W latach 1915-1916 uczył interpretacji Biblii w Teacher's College of Columbia University. Autorem jedynej próby przedstawienia Kaplana metody biblijnej interpretacji jest Eugene Kohn, który był studentem Jewish Theological Seminary, gdzie Kaplan nauczał wówczas homiletyki (E. Kohn, „Mordecai Kaplan as Exegete”). Były uczeń Kaplana podkreśla ${ }^{41}$, że jego nauczyciel dążył przede wszystkim do tego, aby tekst biblijny stał się ważny $\mathrm{i}$ istotny dla współczesnego czytelnika. Tradycyjne podejście w judaizmie polegało na interpretacji Biblii, tymczasem - jak zauważył Kohn - metoda Kaplana polega na reinterpretacji Tory. Na czym polega ta nowość i jakie płyną z tego konsekwencje?

Przede wszystkim Kaplan odszedł od tradycyjnego w judaizmie sposobu myślenia, który jego zdaniem pozostawał wciąż niedojrzały. Jego pierwsze wątpliwości skupiły się na rozumieniu Biblii, szczególnie biblijnych cudów. Największy wpływ na poglądy Kaplana w tej kwestii miał Arnold B. Ehrlich, który był częstym gościem rodziny Kaplanów. Wiele lat później Kaplan napisał o Ehrlichu:

\footnotetext{
${ }^{39}$ Tego rodzaju przekonanie należy traktować jako założenie ontologiczne i jako takie jest bardziej aktem wiary niż aktem wiedzy. W sensie teoriopoznawczym ma taki sam status jak przekonanie, że istnieje rzeczywistość nadprzyrodzona.

${ }^{40}$ Szerzej na temat interpretacji Biblii przez Kaplana zob. Scult 1990, s. 294-318.

${ }^{41}$ Kohn 1952, s. 137-154.
} 
Nauczył mnie przenikać przez rozległe warstwy tradycyjnych komentarzy i docierać do głęboko ukrytych intencji autorów biblijnych. Tak postępując, podkopał moją wiarę w mojżeszowe autorstwo Tory i historyczność cudów ${ }^{42}$.

Ehrlich, który pracował nad komentarzem biblijnym, przychodził do ojca Kaplana, aby dyskutować nad sposobem zastosowania pewnych biblijnych terminów w Talmudzie. Młody Mordecai z pewnością przejmował ten dość krytyczny sposób podejścia do Tory. Zaakceptował wieloautorstwo Biblii i został zwolennikiem biblijnego krytycyzmu (Na początku XX wieku uczeni żydowscy stanęli przed wyzwaniem, aby zmierzyć się z chrześcijańskim krytycyzmem biblijnym, który postulował powolny i ewolucyjny rozwój żydowskiej religii. Julius Wellhausen był najbardziej znanym protestanckim uczonym, który stawiał taką tezę). Według Kaplana najważniejszym tematem Biblii jest kolektywne poszukiwanie przez Żydów znaczenia i wartości. Akceptował wieloautorstwo Tory. Utrzymywał, że niektóre części Pięcioksięgu pochodzą $\mathrm{z}$ okresu powygnaniowego. Zapewniał, że takie stanowisko $\mathrm{w}$ żaden sposób ani nie zagraża żydowskiemu życiu, ani nie podważa znaczenia i roli Tory. W 1914 roku Kaplan napisał artykuł zatytułowany "The Supremacy of the Torah" (Supremacja Tory), w którym stwierdził, że krytycyzm biblijny w żaden sposób nie osłabi autorytetu Biblii ${ }^{43}$.

Takie stanowisko budziło sprzeciw w środowisku żydowskim, lecz Kaplan pozostawał nieugięty i obojętny na krytykę. Według niego status Tory nie opiera się na pochodzeniu, lecz na miejscu w historii ludu żydowskiego. Inaczej mówiąc, autorytet Tory wynika nie z przesłanek teologicznych, lecz historycznych i egzystencjalnych. To, czy pozostanie Tora najwyższą wartością w przyszłości, czy też nie, będzie konsekwencją aktualności i atrakcyjności idei, które są zawarte w Torze. Jeśli autorytet Tory byłby oparty na funkcjonalności, wówczas żadne twierdzenia dotyczące jej pochodzenia nie będą niebezpieczne. To funkcjonalność była pociągająca i przekonująca, a nie pochodzenie Tory. Powyższe stwierdzenie pokazuje, że Kaplan opowiada się za funkcjonalną interpretacją tekstu Tory oraz na jej funkcjonalnym autorytecie.

Tradycyjna wiara co do pochodzenia Tory nie jest jedynym wsparciem dla supremacji Tory. Jeśli ten sposób zawodzi, to inny, wyprowadzony z tego, że Izrael był narzędziem boskiego objawienia, nie jest mnie skuteczny w utrzymaniu jej prymatu $^{44}$.

\footnotetext{
${ }^{42}$ Kaplan 1952, s. 289.

${ }^{43}$ Kaplan 1914, s. 183.

${ }^{44}$ Ibidem, s. 186.
} 
Kaplan był żywiołowo atakowany w żydowskiej prasie z powodu akceptacji biblijnego krytycyzmu, pomimo jego zapewnieniom, że uznaje supremację Tory. Kaplan był nazywany heretykiem, a nawet domagano się, aby zrezygnował z pracy w Seminarium, ponieważ nie może dłużej nauczać tradycyjnego judaizmu. $\mathrm{W}$ jednej $\mathrm{z}$ gazet napisano: „Profesor Kaplan przez zaprzeczenie, że Bóg dał Torę Izraelowi, a także, że wiara w Mesjasza jest błędem, zniszczył najbardziej solidne fundamenty tradycyjnej wiary"45. Organizacja Ortodoksyjnego rabinatu zwołała specjalne zebranie i w jednym punkcie potępiła Kaplana i jego zwolenników, których nazwała „pół-ortodoksami”. Od czasu do czasu Kaplan otrzymywał listy wsparcia dla swojego stanowiska, lecz ze strony swoich kolegów z Seminarium i od liderów judaizmu konserwatywnego spotykał się albo z zimną akceptacją albo z otwartą wrogością.

Aby zaakceptować złożone autorstwo Pięcioksięgu, Kaplan musiał zmierzyć się z problemem objawienia. Także w tej materii, jego podejście ma charakter funkcjonalny. Jeśli Tora jest napisana przez wielu autorów, wtedy oczywiście nie mogła zostać całkowicie objawiona Mojżeszowi. Tora jednakże pozostaje boska w „pośredni sposób” (derivative way). Pochodzi od Boga w tym sensie, że

w żydowskim życiu reprezentuje ucieleśnienie ostatecznych moralnych i duchowych sił, boski charakter, który rozum jest w stanie przyjąć, w żaden sposób nie wchodząc $\mathrm{w}$ konflikt $\mathrm{z}$ wynikami nowoczesnej biblijnej nauki, przeciwnie, raczej je potwierdza ${ }^{46}$.

Tora jest w ten sposób uznawana za wieczną, aczkolwiek nie jest bezpośrednio objawiona przez Boga. Wieczność Tory oznacza, że „nie może nigdy ona przestać funkcjonować jako standard w żydowskim życiu"47. Ustawiczne odwoływanie się do Tory - zdaniem Kaplana - winno polegać na jej reinterpretacji, która ujawnia drugie znaczenie świętego tekstu ${ }^{48}$. To drugie znaczenie zmienia się wraz z upływającym czasem, jako rezultat dostosowywania tekstu Tory do poszczególnych doświadczeń ludzi danej epoki.

Kaplan, zatroskany ustawiczną kontynuacją w judaizmie, chciał być pewny, że jego teoria reinterpretacji nie prowadzi do jakichkolwiek zmian odnośnie do znaczenia podstawowych pojęć. Zasadnicze pojęcia, takie jak objawienie, nie mogą być zmienione całkowicie. Musi istnieć zatem podstawowa ciągłość

${ }^{45}$ Hirsh 1923, s. 2.

${ }^{46}$ Kaplan 1912, s. 7.

${ }^{47}$ Ibidem, s. 8.

${ }^{48}$ Kaplana teoria drugiego znaczenia jest bardzo zbliżona do Schechtera rozumienia Klal Yisrael. Por. Schechter 1908, s. 31-54. 
tożsamości, która łączy naszą obecną interpretację z przeszłością. Owa tożsamość nie oznacza „identyczności doktryny”, lecz „stałość stosunku doświadczenia $\mathrm{z}$ jednej strony i reakcji judaizmu na doświadczenie $\mathrm{z}$ drugiej strony" ${ }^{49}$. Jeśli odnajdujemy wierzenia, które wywołują w nas te same reakcje, jakie rodziły się u naszych przodków pod wpływem tradycyjnych wierzeń, wtedy oczywiście zachowujemy ciągłość tożsamości, której poszukujemy. Stąd Kaplan odrzucił alegoryczną metodę interpretacji, w której proste lub pierwotne znaczenie jest całkowicie zatracone. W metodzie alegorycznej, zwykle identyfikowanej z Filonem, „fakty znikają całkowicie, powiązanie natury i wydarzenia są ignorowane, a cała treść jest odwrócona do góry nogami" ${ }^{50}$.

Kaplan w swoim zamierzeniu nie chciał lekceważyć tradycji, ani też nie próbował po prostu zmieniać tradycyjne pojęcia na nowoczesne. Jego metoda, będąca swoistą demitologizacją, była zatem tłumaczeniem lub przekładaniem myśli $\mathrm{z}$ jednego systemu na inny. Jeśli wierzenia wcielone $\mathrm{w}$ system mityczny zostały odpowiednio przetłumaczone, powinniśmy analogicznie przyjąć owo tłumaczenie, jak to czynili starożytni, i zobaczyć analogiczne implikacje do naszych myśli i zachowań, bez konieczności przyjmowania identycznych pojęć. Nazywanie takiej interpretacji funkcjonalną oznacza, że implikacje i zachowania wypływające $\mathrm{z}$ tej koncepcji powinny być bardzo podobne, chociaż treść reinterpretacji może wyglądać zupełnie inaczej.

Ta koncepcja translacji, opisana przez Kaplana, pozwala zachować pluralistyczny obraz interpretacji biblijnej. Podobnie jak pewne stwierdzenia mogą być przetłumaczone na wiele języków innych niż oryginalny, tak samo ma się sprawa $\mathrm{z}$ archaicznymi wierzeniami, o których dyskutujemy. Przełożenie biblijnej myśli na system Arystotelesa przez Majmonidesa jest zatem nie mniej godne uwagi niż dokonany przez Kaplana przekład na współczesne terminy. Jednocześnie możemy określić adekwatność tych różnych tłumaczeń w celu ustalenia tego, w jakim stopniu została zachowana wierność oryginałowi. Możemy też spojrzeć na tłumaczenie Majmonidesa, aby odpowiedzieć na pytanie, czy kluczowe pojęcia działają w jego systemie w ten sam sposób, w jaki działały pierwotnie. Zdaniem Sculta jedną z zalet propozycji Kaplana jest to, że nie ma tu konieczności wyboru między tradycyjną interpretacją a współczesną, ponieważ obie mogą funkcjonować jednakowo w różnych okolicznościach. Interpretacja rabiniczna, którą odnajdujemy w midraszach,

\footnotetext{
${ }^{49}$ Kaplan 1912, s. 14.

${ }^{50}$ Ibidem, s. 17.
} 
ma tę samą wagę, co nasze własne ${ }^{51}$. Kaplana interpretacja funkcjonalna nie jest po prostu krytyką tradycyjnej myśli w świetle współczesnych wartości, lecz raczej próbą przywrócenia tradycji w naszym obecnym życiu w taki sposób, który - jak sądzi twórca rekonstrukcjonizmu - faktycznie się sprawdza. W ocenie Sculta krytycy Kaplana mylą się, kiedy oskarżają go o bezkrytyczną akceptację współczesnych wartości.

Kaplan używał Biblii jako punktu wyjścia we wszystkim, co pisał. Prowadzone przez niego wykłady z homiletyki były okazją do wyjaśniania Pięcioksięgu z filozoficznego punktu widzenia. Jest dość zaskakujące, że wśród jego wszystkich opublikowanych prac nie znajdziemy systematycznego wykładu na temat Pięcioksięgu. Odnosi się to również do tekstów prawnych i narracyjnych. Kaplan nigdy nie twierdził, że jest biblistą. Jego wiedza na temat języków i literatury starożytnego Bliskiego Wschodu była ograniczona i oparta na źródłach pośrednich. Wprawdzie zapoznawał się z odkryciami archeologicznymi, ale nie interesował się tym obszarem w sposób dogłębny. Stąd zapewne wynika jego niepewność w dziedzinie studiów biblijnych i brak tego rodzaju analiz w jego dziełach. Kaplana wartość jako interpretatora Biblii opiera się w głównej mierze na jego intuicji oraz na jego oratorskim talencie. Nie jedynym, lecz najważniejszym celem, było dla Kaplana spowodowanie, aby biblijny tekst stał się ważny i znaczący dla wspólnoty żydowskiej $^{52}$. Kaplan dążył do wyjaśnienia sposobów funkcjonowania biblijnego umysłu. Kaplan przypomina współczesnym Żydom, że starożytni często nie byli w stanie radzić sobie ze swoimi subiektywnymi stanami, lecz ustawicznie byli zmuszeni do obiektywizacji i reifikacji swoich uczuć. Jak stwierdził:

\begin{abstract}
Starożytni, ze swoją ograniczoną wiedzą, nie potrafili uznać swoich wewnętrznych sił za subiektywne doświadczenie. Wszelkie wewnętrzne doznania pozostające poza ich kontrolą traktowali jako obiektywne i zewnętrzne fakty na równi $\mathrm{z}$ rzeczami, które widzieli wokół siebie. Podobnie jak zewnętrzny świat nie mógł powodować wewnętrznych poruszeń serca i woli - jak myśleli - ponieważ pochodził od jakiegoś bóstwa ${ }^{53}$.
\end{abstract}

Traktowanie biblijnych stwierdzeń jako projekcji jest charakterystyczne nie tylko dla Kaplana. Wśród żydowskich myślicieli jest jednak spotykane raczej sporadycznie. Komentując opowiadanie o Ogrodzie Eden, Kaplan pisze: „Boskie rozczarowanie dziełem stworzenia jest w rzeczywistości rozżaleniem Izraela sposobem, w jaki człowiek często niszczy piękny świat stwo-

${ }^{51}$ Por. Scult 1990, s. 303-304.

${ }^{52}$ Por. ibidem, s. 305.

${ }^{53}$ Kaplan, The Torah and Salvation: A Modern Reinterpretation of the Bible (wykład Kaplana). Cyt. za: Scult 1990, s. 305. 
rzony przez Boga" ${ }^{54}$. Reasumując, bez względu na intencje twórcy rekonstrukcjonizmu żydowskiego takie podejście do Tory prowadzi do jej desakralizacji. Parafrazując powyższe słowa Kaplana, można w tym wypadku odczuwać żal ze sposobu, w jaki człowiek traktuje Słowo Boga skierowane do człowieka.

\section{RECONSTRUCTIONIST DESACRALIZATION OF THE TORAH AND ITS IMPACT ON JEWISH CULTURE TODAY}

\section{Summary}

The influence of the Bible on various cultures, though undeniable, tended to be rather random and secondary. In contrast, the impact of that Sacred Scripture on the culture of Jews was primeval, unadulterated and vital. Therein lies the essential difference. Thus, as a matter of course, one not infrequently refers to the biblical nature of Jewish culture, underscoring the truth that Bible was a constitutive element of that culture. This article, however, is not concerned with yet another analysis of the effect that the Bible has had on Jewish culture, which seems obvious and universally known; instead, it recognizes the fact that in the world today it is culture which exerts a tremendous influence on how the Bible is understood by Jews themselves. This approach is exemplified in Jewish reconstructionism, which effected a veritable revolution in that respect. As it appears, the attitude has ultimately led to the desacralization of the Torah.

\section{Bibliografia}

Baniak J. 2006, Sekularyzacja jako wyzwanie dla religii i Kościoła. Mity czy rzeczywistość, Socjologia religii 4, s. 272-289.

Berger P. 1967, The Sacred Canopy, New York.

Chat E. 2009, Religia w życiu człowieka, Sandomierz.

Chipkin I.S. 1952, Dr. Mordecai M. Kaplan and Jewish Education, [w:] I. Eisenstein, E. Kohn (red.), Mordecai M. Kaplan: An Evaluation, New York, s. 85-118.

Eisenberg J. 1999, Judaizm, Warszawa.

Fromm E. 1968, Szkice z psychologii religii, Warszawa.

Goldsmith E.S. 1990, Kaplan and The Retrieval of the Haskalah, [w:] E.S. Goldsmith, M. Scult R.M. Seltzer (red.), The American Judaism of Mordecai M. Kaplan, New York-London, s. 19-34.

Hirsh H. 1923, Kaplanism and What It Means, Idische Licht, 1, s. 9- 21.

Kaplan M.M. 1981, Judaism as a Civilization. Toward a Reconstruction of American-Jewish Life, Philadelphia, New York.

Kaplan M.M. 1958, Judaism without Supernaturalism, New York.

\footnotetext{
${ }^{54}$ Ibidem.
} 
Kaplan M.M. 1962, The Meaning of God in Modern Jewish Religion, New York. Kaplan M.M. 1964, The Purpose and Meaning of Jewish Existence, Philadelphia. Kaplan M.M. 1914, The Supremacy of the Torah, New York.

Kaplan M.M. 1952, The Way I Have Come, [w:] I. Eisenstein, E. Kohn (red.), Mordecai M. Kaplan: An Evaluation, New York, s. 283-321.

Kaplan M.M. 1912, Paper Read to Meeting of Alumni, Tannersville, New York.

Kaufman W.E. (red.) 1976, Contemporary Jewish Philosophies, New York.

Kaufman W.E. 1981, The Transnatural Theology of Mordecai M. Kaplan, Judaism, 1, s. 45-52.

Kohn E. 1952, Mordecai M. Kaplan As Exegete, [w:] I. Eisenstein, E. Kohn (red.), Mordecai M. Kaplan: An Evaluation, New York.

Ouaknin M.A. 1998, Bóg Żydów, [w:] J. Bottero, M.A. Ouaknin, J. Moingt (red.), Najpiękniejsza historia Boga, Warszawa, s. 28-42.

Piwowarski W. (red.) 1998, Socjologia religii. Antologia tekstów, Kraków.

Radwan M. 1983, Rodowód sekularyzacji, [w:] F. Adamski (red.), Socjologia religii. Wybór tekstów, Kraków, s. 413-427.

Schechter S. 1908, The Study of the Bible, Studies in Judaism, 2, s. 32-54.

Scult M. 1990, Kaplan's Reinterpretation of the Bible, [w:] E.S. Goldsmith, M. Scult, R.M. Seltzer (red.), The American Judaism of Mordecai M. Kaplan, New York-London, s. 294-318.

Seltzer R.M. 1990, Kaplan and Jewish Modernisty, [w:] E.S. Goldsmith, M. Scult, R.M. Seltzer (red.), The American Judaism of Mordecai M. Kaplan, New York-London, s. 1-15.

Serretti M. 2006, Rozpoznawanie Boga, Kielce.

Storey J. 2009, Cultural Theory and Popular Culture. An Introduction, London.

Szczerbiński W. 2014, Charakterystyka kultury żydowskiej w Izraelu i przejawy jej sekularyzacji, Teologia i człowiek, 27, s. 79-107.

Unterman A. 2002, Żydzi. Wiara i życie, Warszawa.

Zdybicka Z. 1977, Człowiek i religia, Lublin. 